\title{
WYBRANE ZAGADNIENIA STOSOWANIA NOMINALNIE PLASKICH BLACH FALDOWYCH I PANELI SAMONOŚNYCH DO REALIZACJI DACHÓW ZAKRZYWIONYCH
}

\begin{abstract}
W przypadku reprezentacyjnych obiektów o rozległym rzucie poziomym, takich jak: hale widowiskowo-sportowe, stadiony, terminale lotnicze, parki rozrywki itp. projektanci często stosują dachy o złożonej geometrii. Projektując tego typu dachy należy odpowiednio wcześnie przeprowadzać analizy technicznoekonomiczne pozwalające przyjąć rozwiązania konstrukcyjne oraz technologie, które $\mathrm{z}$ jednej strony zapewnią odpowiednią ochronę wnętrza obiektu przed wpływami środowiskowymi, a z drugiej strony zagwarantują odpowiedni efekt estetyczny oraz trwałość - przy jednoczesnym zachowaniu określonego poziomu cenowego. Zdecydowanie największe możliwości w zakresie swobodnego kształtowania geometrii dachu oferują konstrukcje stalowe. W pracy zostaną omówione wybrane zagadnienia związane ze stosowaniem nominalnie płaskich blach fałdowych oraz paneli samonośnych przy realizacji dachów o złożonej geometrii na przykładzie dachu terminalu lotniczego w Rzeszowie-Jasionce. Nominalnie płaskie blachy trapezowe oraz samonośne panele dachowe, w połączeniu $\mathrm{z}$ odpowiednio zaprojektowaną konstrukcją stalową, pozwalają na wykonywanie skomplikowanych pod względem geometrycznym, estetycznych oraz funkcjonalnych dachów. Podjęcie decyzji o zastosowaniu nominalnie płaskich elementów, które w trakcie montażu będą w sposób kontrolowany deformowane musi być poprzedzone odpowiednimi analizami w zakresie geometrii oraz wpływu sił generowanych przez wprowadzone deformacje na nośność elementów. Szczególnie w przypadku blach fałdowych wpływ wygięcia wstępnego na nośność może okazać się istotny. Stosowanie nominalnie płaskich elementów w miejsce elementów zakrzywionych (blach i paneli) wpływa na obniżenie kosztów realizacji inwestycji.
\end{abstract}

Słowa kluczowe: blachy fałdowe, panele samonośne, dachy zakrzywione

\footnotetext{
${ }_{1}^{1}$ Autor do korespondencji: Paweł Żwirek, Politechnika Krakowska, ul. Warszawska 24, 31-155 Kraków. 1262820 33,pzwi@pk.edu.pl
} 


\section{Wstęp}

W przypadku reprezentacyjnych obiektów o rozległym rzucie poziomym, takich jak: hale widowiskowo-sportowe, stadiony, terminale lotnicze, parki rozrywki itp. projektanci chętnie stosują dachy o złożonej geometrii. Projektując tego typu dachy należy odpowiednio wcześnie przeprowadzać analizy techniczno-ekonomiczne pozwalające przyjąć rozwiązania konstrukcyjne oraz technologie, które z jednej strony zapewnią odpowiednią ochronę wnętrza obiektu przed wpływami środowiskowymi, a $z$ drugiej strony zagwarantują odpowiedni efekt estetyczny oraz trwałość - przy jednoczesnym zachowaniu określonego poziomu cenowego. Zdecydowanie największe możliwości w zakresie swobodnego kształtowania geometrii dachu dają konstrukcje stalowe. Cechą wspólną obiektów przedstawionych na rys. 1 jest zastosowanie stalowej konstrukcji prętowej pokrytej nominalnie płaskimi blachami trapezowymi oraz aluminiowymi panelami samonośnymi $[9,11,12]$. W pracy zostaną omówione wybrane zagadnienia związane ze stosowaniem zarówno nominalnie płaskich blach fałdowych, jak również nominalnie płaskich paneli samonośnych przy realizacji dachów o złożonej geometrii na przykładzie dachu terminalu lotniczego w RzeszowieJasionce.

a)

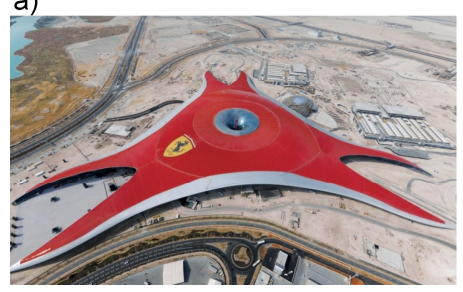

b)

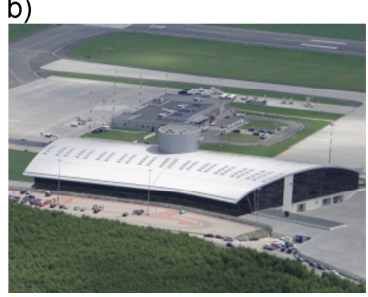

c)

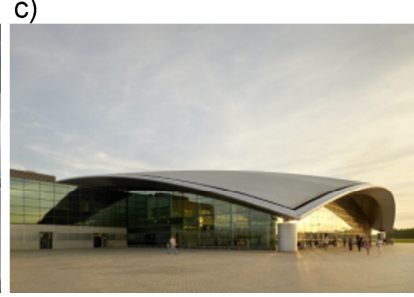

Rys. 1. Przykłady dachów pokrytych samonośnymi panelami metalowymi: a) Ferrari World Abu Dhabi [13], b) terminal lotniczy w Łodzi [14], d) terminal lotniczy w Rzeszowie Jasionce [10]

Fig. 1. Examples of roofs covered with self-supporting metal panels: a) Ferrari World Abu Dhabi [13], b) air terminal in Łódź [14], d) air terminal in Jasionka Rzeszów [10]

\section{Opis technologii}

Opis technologii produkcji oraz zagadnienia konstrukcyjne związane ze stosowaniem samonośnych paneli metalowych - nie tylko nominalnie płaskich - zostały szerzej omówione przez autora w pracy [15]. Systemy pokryć dachowych wykonywanych z samonośnych paneli metalowych $[5,6,9,11,12]$ składają się z uchwytów nazywanych klipami oraz samonośnych paneli metalowych (por. rys. 2). Klipy stanowią punktowe podparcie dla paneli dachowych. Stosowana pod panelami miękka wełna mineralna pełni jedynie funkcję termoizolacji - nie uczestniczy w przenoszeniu obciążeń powierzchniowych z paneli na warstwy przegrody dachowej znajdujące się pod termoizolacją (por. rys. 2). 
Okoliczność tą należy uwzględnić przy wymiarowaniu elementów, do których mają być przykręcone klipy.

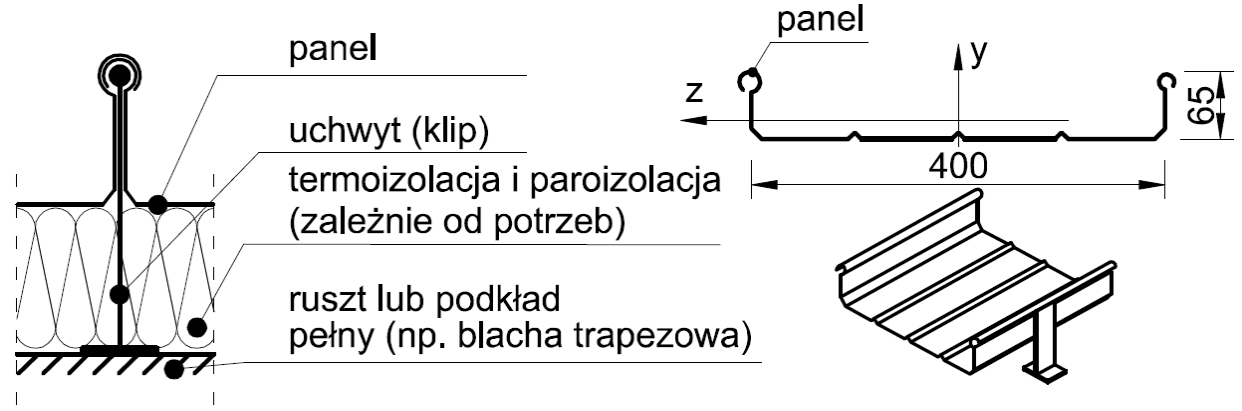

Rys. 2. Elementy składowe systemu samonośnych paneli dachowych oraz przykładowe wymiary panela dachowego [15]

Fig. 2. Component elements of the system of self-supporting roof panels and example dimensions of the roof panel [15]

Coraz wyższe wymagania w zakresie izolacyjności cieplnej przegród budowlanych spowodowały, że pierwotnie aluminiowe klipy są zastępowane przez klipy z tworzyw sztucznych, np. ultramidu A3WG10 wzmocnionego włóknem szklanym, który cechuje się dużą wytrzymałością, niskim współczynnikiem tarcia oraz jednocześnie niskim współczynnikiem przewodzenia ciepła $\lambda=0,37 \mathrm{~W} /(\mathrm{m} \cdot \mathrm{K})$.

Ze względu na trwałość, niską wagę oraz łatwość formowania panele przeważnie wykonywane są jako aluminiowe. Przykładowy kształt przekroju poprzecznego panelu dachowego przedstawia rys. 2. Panele dachowe mogą być produkowane na budowie w specjalnych urządzeniach zwanych rollformerami (rys. 3a) i mogą mieć długość kilkudziesięciu metrów - równą wymiarowi połaci dachowej (rys. 3b). Sąsiednie panele łączone są przez mechaniczne zaciskanie rąbka (rys. 3c), które z jednej strony zapobiega oderwaniu pokrycia przez wiatr, a z drugiej strony nie krępuje odkształceń termicznych (poślizg paneli na główkach klipów) oraz umożliwia odprowadzanie wilgoci spod paneli.

W najprostszych rozwiązaniach stosuje się panele prostoliniowe o stałym przekroju poprzecznym (rys. 2). Niemniej jednak posiadany przez producentów park maszynowy pozwala na wykonywanie niezwykle skomplikowanych, pod względem geometrycznym, pokryć dachowych (por. rys 9).

$\mathrm{Na}$ rys. 4 przedstawiono różne rozwiązania konstrukcyjne przegród dachowych $\mathrm{z}$ pokryciem wykonanym $\mathrm{z}$ samonośnych paneli metalowych montowanych za pośrednictwem klipów bezpośrednio na ruszcie stalowym (rys. 4a) lub na blasze trapezowej (rys. $4 \mathrm{~b} \div$ e). Rozwiązania przedstawione na rys. $4 \mathrm{a} \div \mathrm{d}$ zostały szczegółowo omówione przez autora $\mathrm{w}$ pracy [15]. W przypadku terminala lotniczego w Rzeszowie Jasionce zastosowane zostało 
rozwiązanie przedstawione na rys. 4e, które opisano w p. 3 niniejszego artykułu.
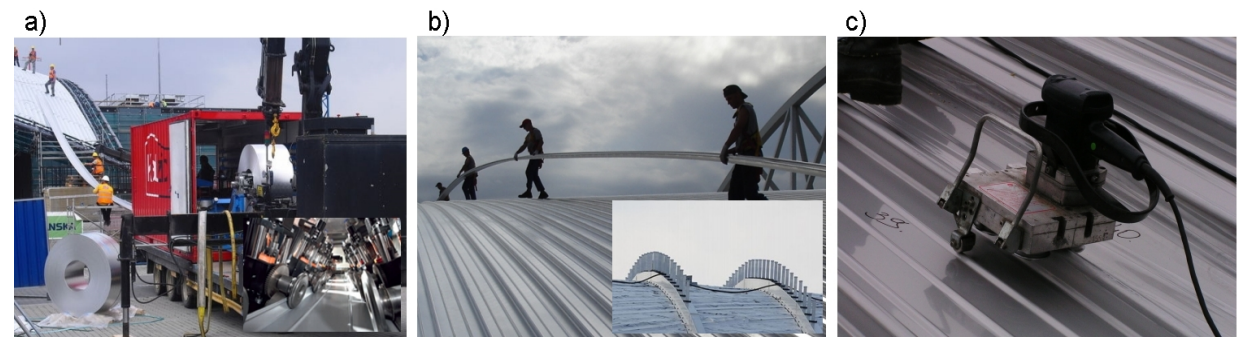

Rys. 3. a) produkcja paneli w rollformerze, b) układnie paneli na klipach, c) zaciskanie rąbków podłużnych

Fig. 3. a) production of panels in rollformer, b) laying of panels at the clips, c) tightening oblong hems

a)

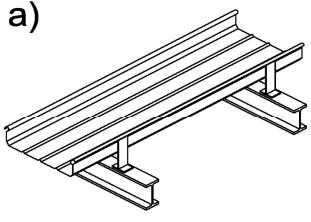

c)
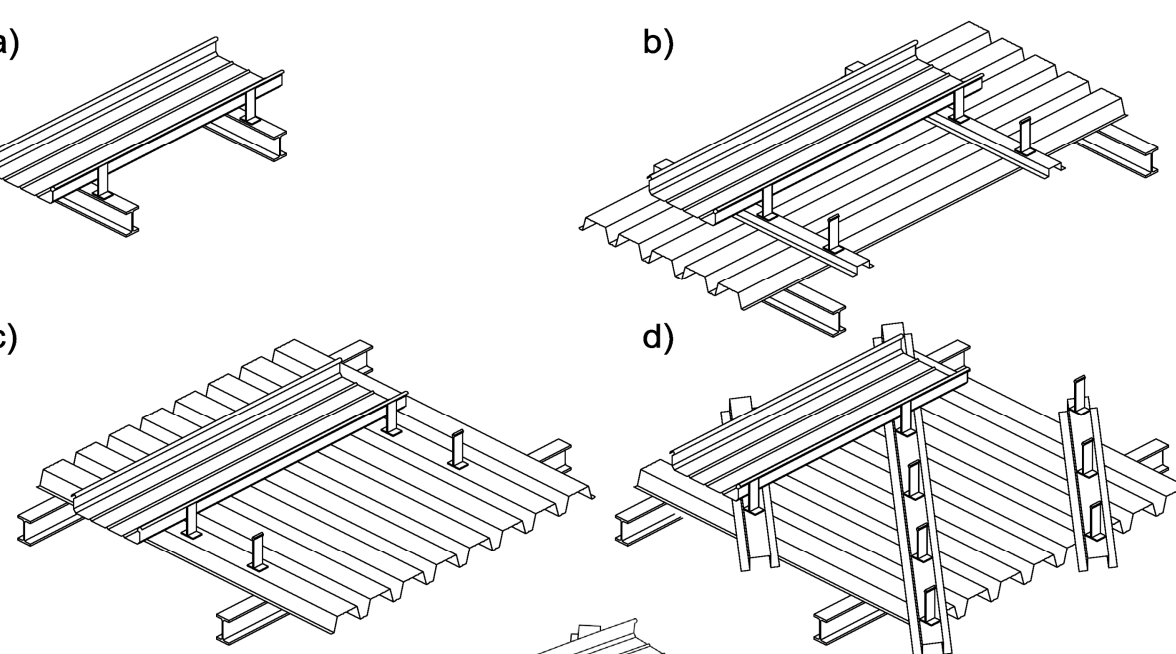

e)

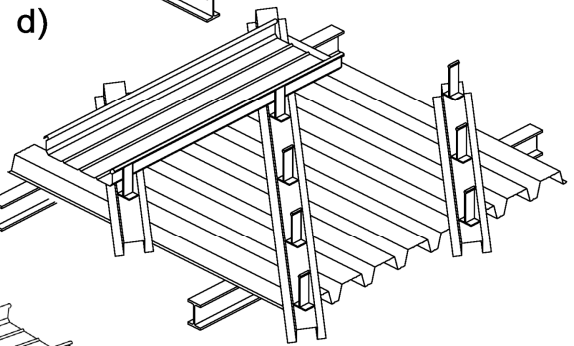

Rys. 4. a $\div$ d) przykładowe rozwiązania dachów z poryciem z paneli samonośnych wg [15] e) rozwiązanie zastosowane na dachu terminala lotniczego w Rzeszowie-Jasionce

Fig. $4 . \mathrm{a} \div$ d) examples of solutions of the roofs with covering with self-supporting panels according to [15] e) solution applied on the roof of an air terminal in Rzeszow-Jasionka 


\section{Przykłady realizacji}

Dach terminala lotniczego w Rzeszowie-Jasionce o kształcie przedstawionym na rys. 1c, 5e został $\mathrm{w}$ całości wykonany z zastosowaniem nominalnie płaskich arkuszy blach fałdowych oraz samonośnych paneli dachowych o stałej szerokości. Konstrukcja nośna dachu składa się z zakrzywionych dźwigarów pełnościennych oraz przebiegających prostopadle do nich zakrzywionych płatwi kratowych (rys. 5b) z odpowiednio ukształtowanymi pasami górnymi (rys. 5c). $\mathrm{Na}$ płatwiach ułożona jest nominalnie płaska blacha trapezowa Arcelor Mittal ACP 135/315/1,0 (w układzie jednoprzęsłowym lub trójprzęsłowym por. rys. 6) ze stali S320GD mocowana do płatwi za pomocą kołków wstrzeliwanych Hilti X-ENP 19. Sąsiednie arkusze blachy są połączone wkrętami samowiercącymi Koelner OC-48022.

a)

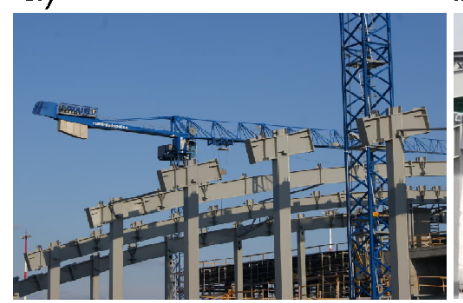

d)

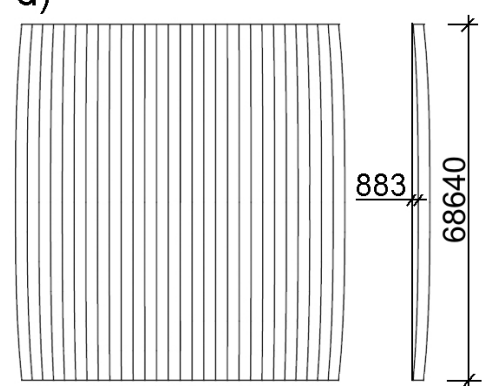

b)

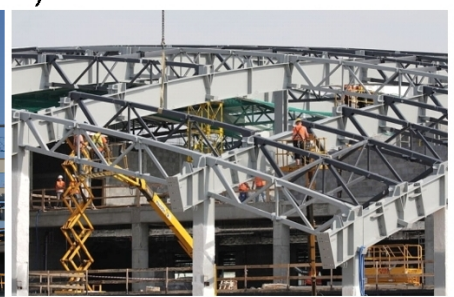

e) c)

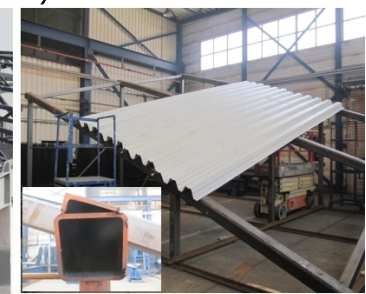

f)

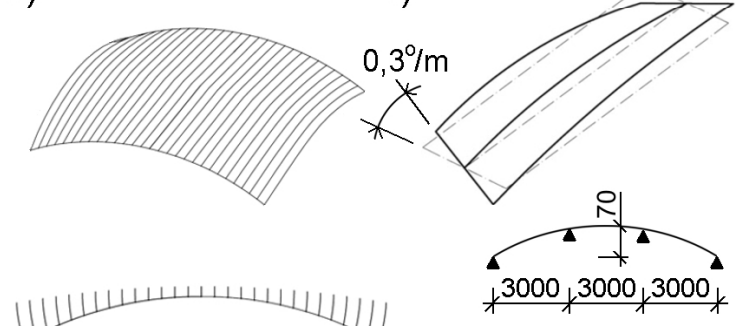

Rys. 5 a), b) widok konstrukcji stalowej w trakcie montażu, c) próbny montaż blachy trapezowej, d) e) model połaci dachowej aproksymowanej za pomocą zbioru kolejnych pasm o stałej szerokości, f) wstępna deformacja arkusza blachy

Fig. 5. a), b) view of the steel structure in the course of the assembly, c) test assembly of the metal trapezoidal sheet , d) e) model of the roof slope approximate with the set of another bands about the permanent width, f) preliminary deformation of the metal sheet

$\mathrm{Na}$ blasze trapezowej wyklejona jest samoprzylepna paroizolacja Kalzip $\mathrm{z}$ folią aluminiową. Termoizolacja wykonana jest $\mathrm{z}$ dwóch warstw wełny mineralnej Rockwool o łącznej grubości 220 mm. Klipy aluminiowe Kalzip L120 z podkładką termiczną DTK5 przykręcane są za pomocą wkrętów Ejot JT3-X2-6,0x36 do profili kapeluszowych o ukośnym przebiegu względem fałd blachy 
(por. rys. 4d). Warstwę zewnętrzną stanowią aluminiowe samonośne panele dachowe Kalzip o profilu $65 / 400$ i grubości $0,9 \mathrm{~mm}$. Układ elementów konstrukcyjnych przegrody dachowej przedstawia rys. 4e. Ze względu na kształt połaci dachowej nie było możliwe ułożenie samonośnych paneli dachowych wyłącznie prostopadle lub równolegle do fałd blachy trapezowej (por. rys. 4 b,c). $\mathrm{Z}$ tego powodu zastosowane zostało rozwiązanie przedstawione na rys. $4 \mathrm{e}$ z ukośnym przebiegiem profili kapeluszowych, za pośrednictwem których klipy są mocowane do blach trapezowych. Rozwiązanie takie powoduje bardziej równomierne obciążenie blach trapezowych aniżeli w przypadku rozwiązania przedstawionego na rys. 4b, gdzie obciążenie jest przekazywane liniowo (na kolejne fałdy blachy w tej samej odległości od podpory), czy też rozwiązania przedstawionego na rys. $4 \mathrm{c}$ - gdzie obciążenia z paneli przekazywane są punktowo

\subsection{Blacha trapezowa}

Ze względu na zakrzywiony kształt połaci dachowej naturalne wydawało się zastosowanie blach fałdowych łukowych. Należy jednak podkreślić, że powierzchnia połaci dachowej terminala lotniczego w Rzeszowie-Jasionce cechuje się zróżnicowanymi wartościami promienia krzywizny.

Wspomniana okoliczność spowodowałaby konieczność stosowania blach trapezowych łukowych o zróżnicowanych promieniach krzywizny. Niewielki asortyment blach łukowych, w porównaniu $\mathrm{z}$ blachami płaskimi, oraz wyższa cena jednostkowa związana m.in. $\mathrm{z}$ wyższymi kosztami produkcji i transportu sprawiła, że przeanalizowano możliwość wykonania pokrycia dachu z blach płaskich wyginanych $\mathrm{w}$ trakcie montażu. Poszczególne fałdy pierwotnie płaskich arkuszy blach fałdowych miały być w trakcie montażu wstępnie wyginane w kierunku podłużnym i poprzecznym, skręcane oraz odkształcane poprzecznie na skutek zamierzonej zmiany szerokości fałd [7] (por. rys. 5f). Aby oszacować wielkość wspomnianych deformacji opracowano trójwymiarowy model komputerowy połaci dachowej, która następnie została aproksymowana za pomocą kolejno ułożonych obok siebie pasm o stałej szerokości (por. rys. 5 d,e) - zbliżonej do szerokości krycia pojedynczej blachy trapezowej. Największe deformacje występowały w obrębie pasm skrajnych oraz w rejonie naroży połaci dachowej. Aby uzyskać aproksymację kształtu skrajnego pasma (rys. 5d) za pomocą zbioru trójprzęsłowych arkuszy blachy o długości 9,000m należało skręcać osie kolejnych arkuszy o około $0,7^{\circ}$. Przy szerokości krycia pojedynczego arkusza blachy $3 \times 315=945 \mathrm{~mm}$ dawało to różnicę długości zakładu na końcach arkusza o wartości $945 \operatorname{tg}(0,7)=11 \mathrm{~mm}$. Przeprowadzone próby wykazały możliwość zastosowania takiego rozwiązania. Deformacje związane ze skręceniem (por. rys. 5f), zmianą szerokości oraz wygięciem poprzecznym arkuszy blachy nie budziły wątpliwości osiągając wartości porównywalne do tolerancji wykonania blach [3]. Wartość strzałki wygięcia wstępnego arkusza blachy 
70/9000=1/128 (por. rys. 5f) mogła się wydawać stosunkowo mała, jednak jak wykazały późniejsze analizy miała ona duży wpływ na nośność blachy [4].

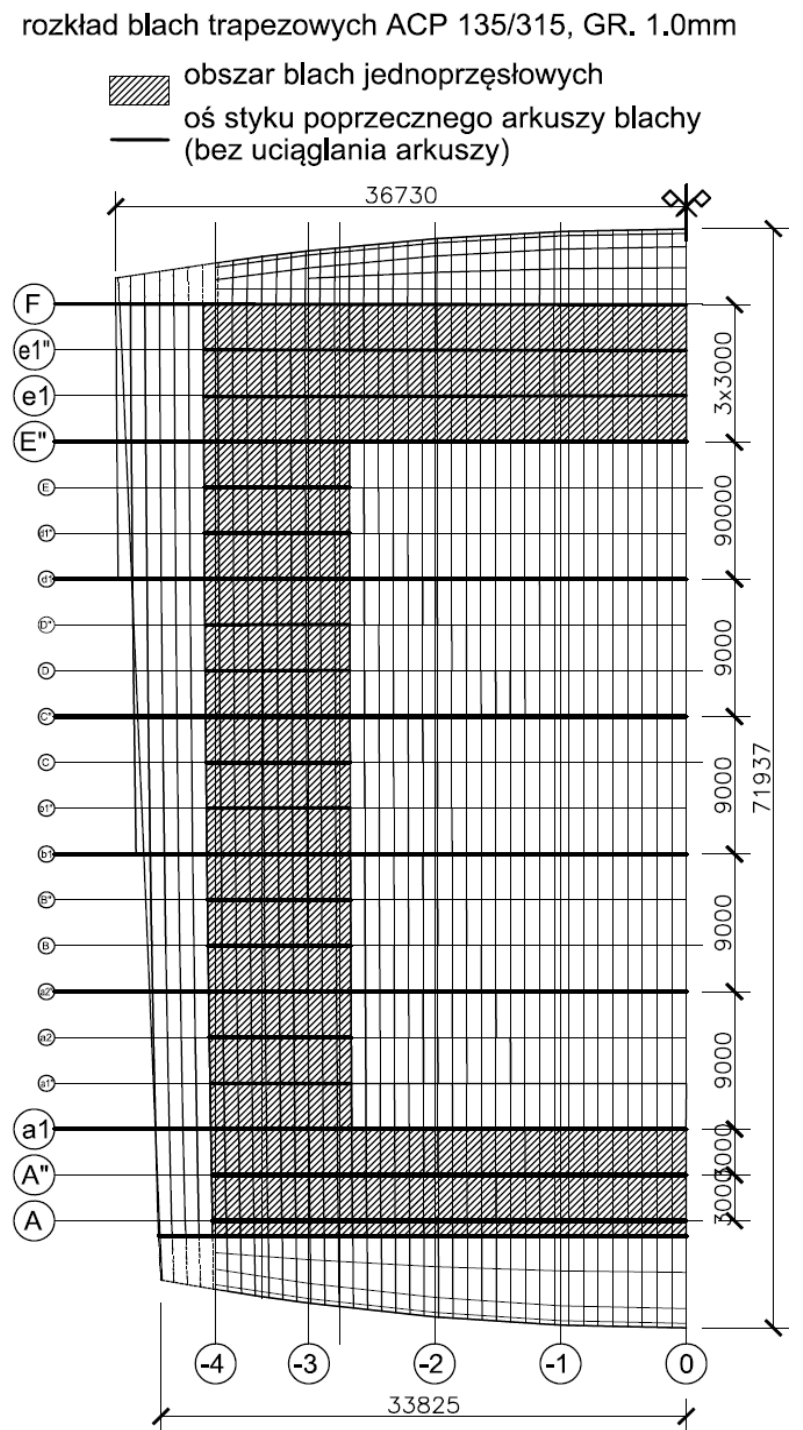

Rys. 6. Podział blach trapezowych na dachu terminala lotniczego w Rzeszowie-Jasionce

Fig. 6. Allocation of metal trapezoidal sheets on the roof of an air terminal in Rzeszow-Jasionka

Wpływ wygięcia wstępnego na nośność wieloprzęsłowej blachy fałdowej może być uwzględniony w obliczeniach poprzez superponowanie: sił przekrojowych powstających od wygięcia wstępnego oraz sił od obciążeń zewnętrznych (rys. 7). 
Przykładowo dla blachy ACP 135/315/1,0 w układzie trójprzęsłowym, obciążonej obciążeniem o wartości obliczeniowej $3,0 \mathrm{kN} / \mathrm{m} 2$ zestawiono na rys. 7 wartości sił przekrojowych dla różnych wartości strzałek wygięcia $f$.

$\mathrm{Na}$ rysunku 8 pokazano jak zmienia się relacja pomiędzy siłami przekrojowymi od wygięcia wstępnego a siłami od obciążeń zewnętrznych (por. rys. 7). Jak widać dla analizowanych promieni krzywizny dachu siła poprzeczna od wygięcia wstępnego jest porównywalna z siłą poprzeczną od obciążeń zewnętrznych. Natomiast wartość momentu zginającego nad podporą pośrednią od wygięcia wstępnego blachy może być nawet 5 . krotnie większa od momentu generowanego przez ciężar własny i obciążenia zmienne (śnieg) - mimo wspomnianych wcześniej raczej niewielkich strzałek wygięcia wstępnego blachy. Wpływ wygięcia wstępnego na nośność blach fałdowych został szerzej omówiony w pracy [4].

$g+q$
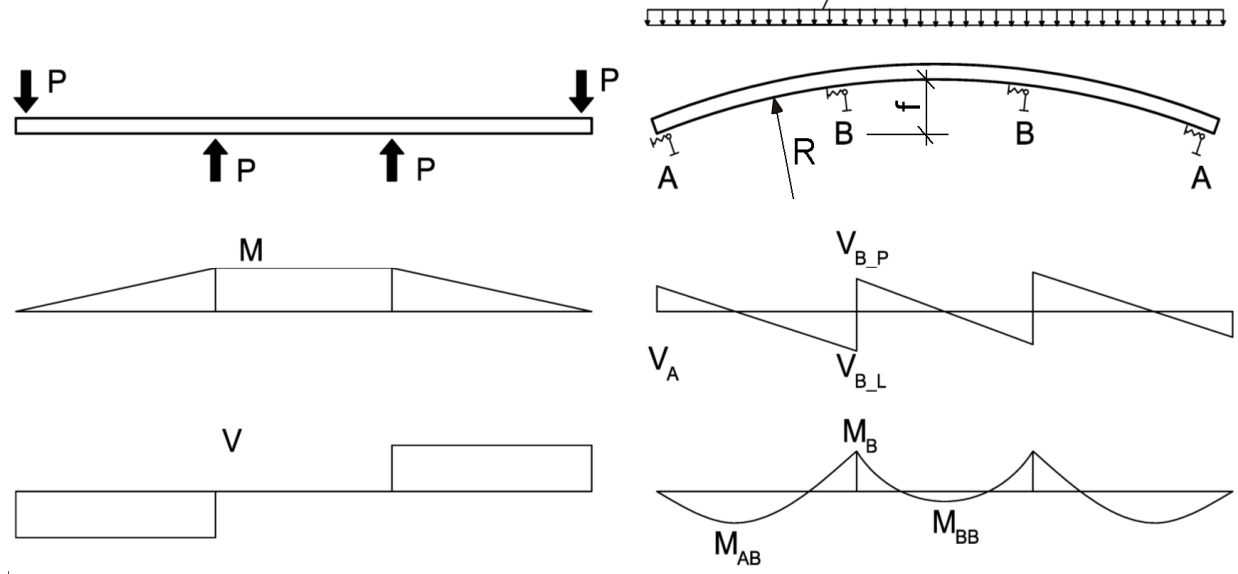

\begin{tabular}{|c|c|c|c|c|c|c|c|c|c|c|c|c|}
\hline 1 & 2 & 3 & 4 & 5 & 6 & 7 & 8 & 9 & 10 & 11 & 12 & 13 \\
\hline & & \multicolumn{7}{|c|}{ wygięcie wstępne } & \multicolumn{8}{|c|}{ ciężar własny + śnieg } \\
\hline $\mathrm{Lp}$ & $\begin{array}{c}\mathrm{R} \\
{[\mathrm{m}]}\end{array}$ & $\begin{array}{c}\mathrm{f} \\
{[\mathrm{mm}]}\end{array}$ & $\begin{array}{c}\mathrm{P},|\mathrm{V}| \\
{[\mathrm{kN} / \mathrm{m}]}\end{array}$ & $\begin{array}{c}\mathrm{M} \\
{[\mathrm{kNm} / \mathrm{m}]}\end{array}$ & $\begin{array}{c}\mathrm{N}_{\mathrm{AB}} \\
{[\mathrm{kN} / \mathrm{m}]}\end{array}$ & $\begin{array}{c}\mathrm{N}_{\mathrm{BB}} \\
{[\mathrm{kN} / \mathrm{m}]}\end{array}$ & $\begin{array}{c}\mathrm{M}_{\mathrm{AB}} \\
{[\mathrm{kNm} /} \\
\mathrm{m}]\end{array}$ & $\begin{array}{c}\mathrm{M}_{\mathrm{B}} \\
{[\mathrm{kNm} / \mathrm{m}]}\end{array}$ & $\begin{array}{c}\mathrm{M}_{\mathrm{BB}} \\
{[\mathrm{kNm} / \mathrm{m}]}\end{array}$ & $\begin{array}{c}\mathrm{V}_{\mathrm{A}} \\
{[\mathrm{kN} / \mathrm{m}]}\end{array}$ & $\begin{array}{c}\mathrm{V}_{\mathrm{B}} \mathrm{L} \\
{[\mathrm{kN} / \mathrm{m}]}\end{array}$ & $\left.\begin{array}{c}\mathrm{V}_{\mathrm{B}} \mathrm{P} \\
{[\mathrm{kN} / \mathrm{m}]}\end{array}\right]$ \\
\hline 1 & 200 & 52 & 1,58 & $-4,75$ & $-0,73$ & $-0,45$ & 2,16 & $-2,70$ & 0,68 & 3,60 & $-5,40$ & 4,50 \\
\hline 2 & 125 & 83 & 2,53 & $-7,60$ & $-1,16$ & $-0,70$ & 2,16 & $-2,70$ & 0,68 & 3,60 & $-5,40$ & 4,50 \\
\hline 3 & 100 & 103 & 3,17 & $-9,51$ & $-1,46$ & $-0,88$ & 2,16 & $-2,70$ & 0,68 & 3,60 & $-5,40$ & 4,50 \\
\hline 4 & 75 & 138 & 4,23 & $-12,68$ & $-1,94$ & $-1,19$ & 2,16 & $-2,70$ & 0,68 & 3,60 & $-5,40$ & 4,50 \\
\hline
\end{tabular}

Rys. 7. Wykresy sił przekrojowych dla blachy z wygięciem wstępnym oraz zestawienie sił przekrojowych [4]

Fig. 7. Diagram of cross-sectional forces for the metal sheet with the preliminary curvature and cross-section force collection [4] 


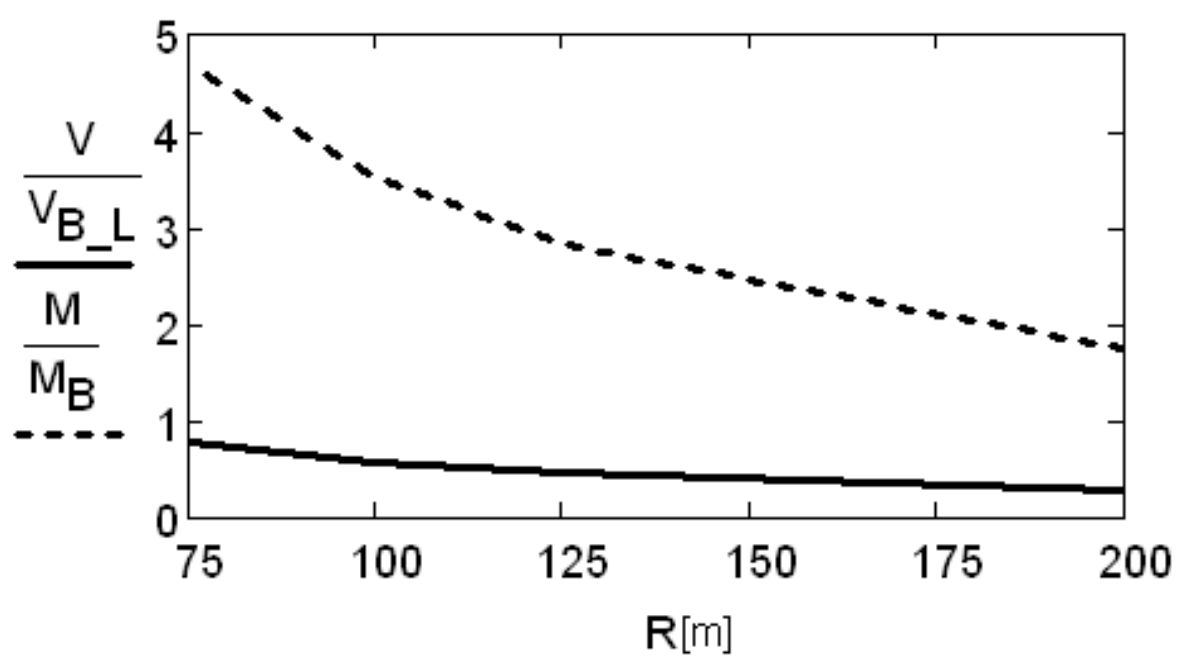

Rys. 8 Wykresy V/V $\mathrm{V}_{\mathrm{B} \_\mathrm{L}}$ oraz $\mathrm{M} / \mathrm{M}_{\mathrm{B}}$ zależnie od promienia R krzywizny dachu [4]

Fig. 8. Diagram of $V / V_{B_{-} L}$ and $M / M_{B}$ depending on the $R$ radius of the curvature of the roof [4]

\subsection{Samonośne panele dachowe}

Możliwości w zakresie formowania kształtów samonośnych paneli dachowych (rys. 9) powodują, że wykonanie nawet najbardziej skomplikowanych pod względem geometrycznym pokryć dachowych nie stanowi większego problemu. Pokazane na rys. 9 panele nie mogą być na ogół produkowane w rollformerach bezpośrednio na budowie. Konieczność wcześniejszego produkowania wspomnianych elementów w fabrykach, koszty transportu oraz konieczność spawania na budowie w celu uzyskania pasma paneli o odpowiedniej długości powodują, że cena rozwiązań z wykorzystaniem tego typu paneli jest znacznie wyższa aniżeli płaskich paneli o stałej szerokości - które można bezpośrednio na budowie produkować w postaci jednego panela (pasma) o długości równej długości połaci dachowej. Dodatkowo spawanie arkuszy wpływa niekorzystnie na estetykę pokrycia dachowego. Zgodnie z [8], w przypadku dachu terminala lotniczego w Rzeszowie-Jasionce (ze względu na promień gięcia względem słabszej osi panelu - oś ,z” na rys. 2) możliwe było zastosowanie paneli nominalnie płaskich. Panele nominalnie płaskie, gięte w sposób tzw. "naturalny", można w przypadku profilu Kalzip 65/400 stosować już przy promieniu krzywizny o wartości $\mathrm{R}=48 \mathrm{~m}$ [8]. Określenie gięcie "naturalne" oznacza wyginanie nominalnie płaskich paneli dachowych odpowiednio do krzywizny dachu.

Pewne wątpliwości budziła możliwość wygięcia paneli w płaszczyźnie środnika (względem osi „y” panelu wg rys. 2), tak aby uzyskać dla skrajnych paneli deformację pokazaną na rys. $5 \mathrm{~d}$. W tym celu wyznaczono wartość siły poziomej potrzebnej do wygięcia panelu środnika: 


$$
q_{z}=f_{z} \frac{384 E J_{y}}{5 L^{4}}=2,34 \mathrm{~N} / \mathrm{m}
$$

gdzie: $E=70 G P a$ - moduł sprężystości aluminium

$J_{y}=1094 \mathrm{~cm}^{4}$ - moment bezwładności panela (grubość materiału $\mathrm{t}=0,9 \mathrm{~mm}) \mathrm{z}$ rys. 2 względem osi ,y”

$f_{z}=883 \mathrm{~mm}-$ por. rys. $5 \mathrm{~d}$

$\mathrm{L}=68640 \mathrm{~mm}$ - por. rys. $5 \mathrm{~d}$

Wobec bardzo małej wartości siły potrzebnej do odpowiedniego wygięcia panela $\mathrm{w}$ płaszczyźnie środnika zdecydowano się ostatecznie na zastosowanie nominalnie płaskich paneli o stałym kształcie przekroju poprzecznego. Stosowanie paneli o stałej szerokości ma jeszcze jedną istotną zaletę - pozwala wyeliminować kosztowny nadzór geodezyjny, którego wymaga stosowanie wybranych paneli o kształtach przedstawionych na rys. 9.
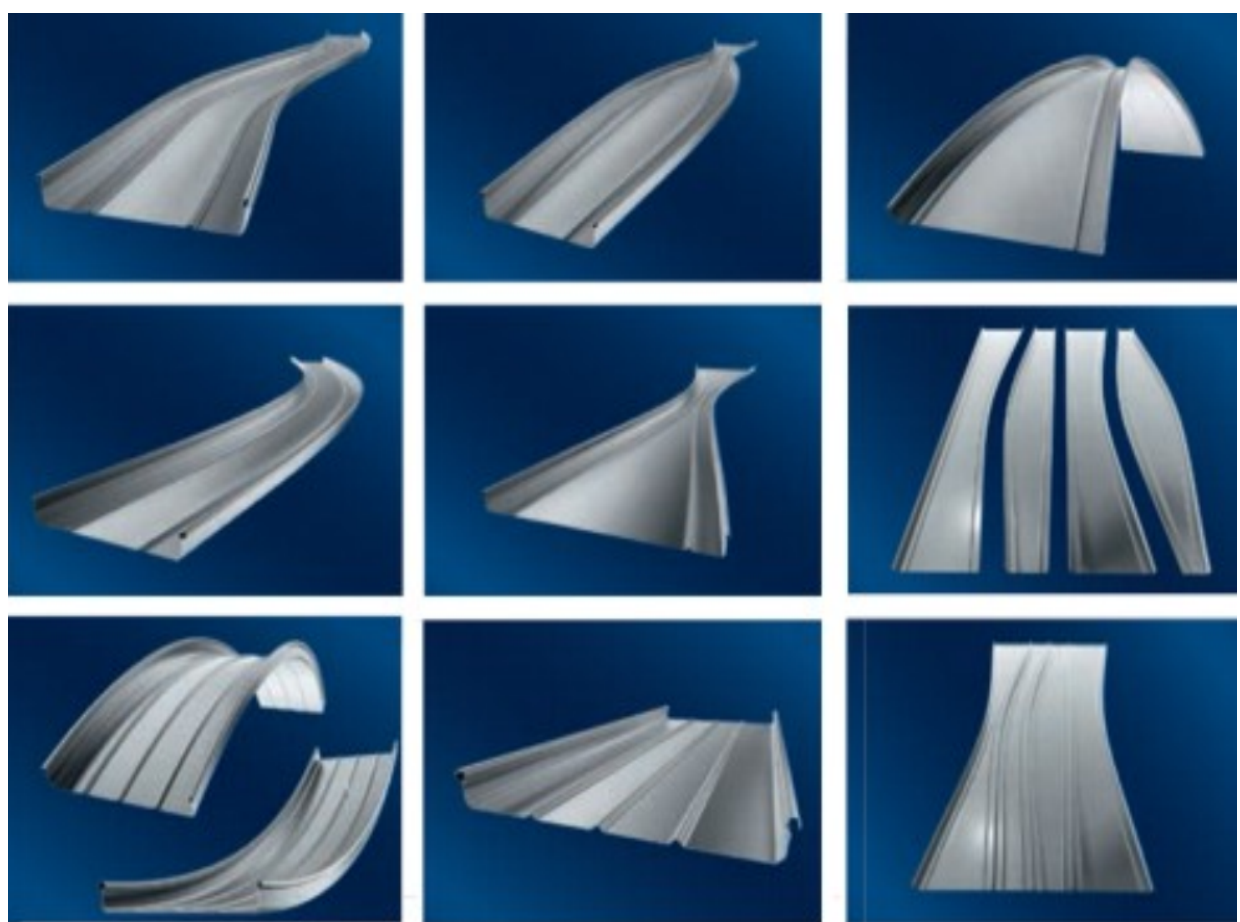

Rys. 9. Przykładowe kształty paneli dachowych o zmiennej geometrii [11]

Fig. 9. Sample shapes of roof panel about the variable geometry [11] 


\section{Podsumowanie}

Nominalnie płaskie blachy trapezowe oraz samonośne panele dachowe, w połączeniu z odpowiednio zaprojektowaną konstrukcją stalową, pozwalają na wykonywanie skomplikowanych pod względem geometrycznym, estetycznych oraz funkcjonalnych dachów. Podjęcie decyzji o zastosowaniu nominalnie płaskich elementów, które w trakcie montażu będą w sposób kontrolowany deformowane musi być poprzedzone odpowiednimi analizami w zakresie geometrii oraz wpływu sił generowanych przez wprowadzone deformacje na nośność elementów. Szczególnie w przypadku blach fałdowych wpływ wygięcia wstępnego może okazać się istotny. Stosowanie nominalnie płaskich elementów w miejsce elementów zakrzywionych (blach i paneli) wpływa na obniżenie kosztów realizacji inwestycji.

\section{Literatura}

[1] Allgemeine Bauaufsichtliche Zulassung Z-14.1-181 Kalzip - Aluminium Stehfalzprofil - Dach.

[2] Allgemeine Bauaufsichtliche Zulassung Z-14.1-419 Aluminium-StehfalzprofilDachelemente Falz-Ripp.

[3] Aprobata Techniczna ITB AT-15-3429/2011 Stalowe blachy profilowane MAUKA, BROMO, ACP-, AC-, TR-, V-, TR 35, TR 40, TS 40, TR 50, TR 60, TR 70, TR 84, TR 94, TR 150, TR 160, LT 40, LT 70, EP-, HACIERBA, HACIERCO, FREQUENCE-, FLOLINE-, SOFTLINE-, HAIRGALBE-, PAMPA-, COFRASOL-. PMA-. Instyut Techniki Budowlanej, Warszawa 2012

[4] Pięciorak E., Żwirek P.: Wpływ wygięcia wstępnego na nośność blachy fałdowej, „Izolacje: budownictwo, przemysł, ekologia”, nr 11-12/2011.

[5] PN-EN 14782:2008 Samonośne blachy metalowe do pokryć dachowych, okładzin zewnętrznych i wewnętrznych. Charakterystyka wyrobu i wymagania.

[6] PN-EN 508-2:2010 Wyroby do pokryć dachowych z metalu. Charakterystyka wyrobów samonośnych z blachy stalowej, aluminiowej lub ze stali odpornej na korozję. Część 2: Aluminium.

[7] Reichhart A.: Analiza powłok z blach fałdowych. „Nowoczesne Hale”, nr 1/2011

[8] Systemy Kalzip, Podręcznik techniki, planowania i konstrukcji, Kalzip, Adhoc media gmbh:901:PL:08/2009

[9] www.aluform.de [dostęp: 8 kwietnia 2015 r.]

[10] www.apa.krakow.pl [dostęp: 8 kwietnia 2015 r.]

[11] www.bemo.com.de [dostęp: 8 kwietnia $2015 \mathrm{r}$.]

[12] www.kalzip.com [dostęp: 8 kwietnia 2015 r.]

[13] www.me.com.pl [dostęp: 8 kwietnia 2015 r.]

[14] www.rotwl.pl [dostęp: 8 kwietnia 2015 r.]

[15] Żwirek P.: Wybrane zagadnienia projektowania dachów z pokryciem metalowym, „Czasopismo Techniczne”, nr 2-A/1/2011 


\title{
SELECTED ISSUES OF USE OF NOMINALLY FLAT CORRUGATED SHEETS AND SELF-SUPPORTING ROOF PANELS FOR CONSTRUC- TION OF CURVED ROOFS
}

\begin{abstract}
S u m m a r y
In case of representative objects with a large horizontal projection, such as performance and sports halls, stadiums, airport terminals, amusement parks, etc., designers often use roofs with complex geometry. At the structural design stage early technical and economical analysis should be performed for this type of roofs for concluding solutions and technology that on the one hand provide adequate protection inside of an object against environmental influences, on the other hand, ensures an appropriate aesthetic and durability - while maintaining a specific price level. The greatest opportunities for the free shaping of structure geometry provide steel structures. The paper will discuss selected issues associated with the use of nominally flat corrugated sheets and self-supporting panels in the construction of roofs with complex geometry on the example of the airport terminal in Rzeszów-Jasionka. Nominally flat corrugated sheets and self-supporting roof panels, in conjunction with a properly designed steel structure, allow to construct geometrically complicated, aesthetic and functional roofs. The decision on use nominally flat pieces which are deformed in a controlled way during installation must be preceded by appropriate analyzes in the field of geometry and impact of forces generated by the deformation placed on the load capacity of the elements. Particularly in the case of corrugated sheets the influence of initial bending on load capacity can be significant. The use of nominally flat panels in place of the curved elements (corrugated sheets and roof panels) reduces the cost of the investment.
\end{abstract}

Keywords: corrugated sheets, self-supporting panels, curved roofs

Przestano do redakcji:30.05.2015

Przyjęto do druku:10.01.2016

DOI: $10.7862 / \mathrm{rb} .2015 .214$ 